
NBSIR 79-1953

$\because$

FEB 271981

\section{SIMULATED PRECIPITATION REFERENCE MATERIALS, III}

E.R. Deardorff, T.C. Rains, and W.F. Koch

Inorganic Analytical Research Division

National Measurement Laboratory

National Bureau of Standards

U.S. Department of Commerce

Washington, D.C. 20234

April 1980

Issued September 1980

Prepared for

U.S. Environmental Protection Agency

Environmental Research Center

Research Triangle Park; NC 27711

and

U.S. Department of the Interior

Geological Survey

Box 25046, MS 204C

Denver, CO 80226

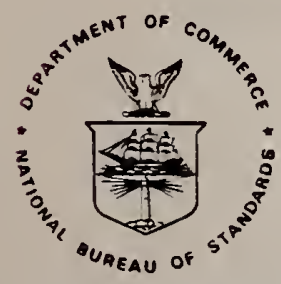

U.S. DEPARTMENT OF COMMERCE, Philip M. Klutznick, Secretary

Luther H. Hodges, Jr., Deputy Secretary

Jordan J. Baruch. Assistant Secretary for Productivity, Technology, and Innovation

NATIONAL BUREAU OF STANDARDS. Ernest Ambler, Director 

TABLE OF CONTENTS

$\underline{\text { Page }}$

1. INTRODUCTION. . . . . . . . . . . . . . . 1

2. EXPERIMENTAL DETAILS. . . . . . . . . . . 2

2.1 General Considerations . . . . . . . . . 2

2.2 Preparation of Reference Materials ....... 2

2.3 Ampouling. . . . . . . . . . . . . . . 3

2.4 Numbering Sequence . . . . . . . . . . . 3

2.5 Analysis of Ampoules.............. 4

2.5.1 pH Measurements .......... . 4

2.5.2 Conductivity Measurements . . . . . . 5

2.5.3 Acidity Measurements.......... 5

2.5.4 Determination of Anions . . . . . . . 5

2.5.5 Analysis for Cations. . . . . . . . 5

2.5.5.1 Measurement for Ammonium Ion . . 5

2.5.5.2 Metals by Atomic Absorption

and Flame Emission . . . . . 6

3. ANALYTICAL RESUltS. . . . . . . . . . . . 6

4. DISCUSSION. . . . . . . . . . . . . 6

5. RE-EXAMINATION OF 1975 SAMPLES. . . . . . . . . 7

6. RE-EXAMINATION OF 1977 SAMPLES. . . . . . . . . . 7

7. INSTRUCTIONS FOR USE. . . . . . . . . . . . . 7

7.1 Series 910000 and Series 920000. . . . . . . . 7

7.2 Series 930000 and Series 940000 . . . . . . . . 8

7.2.1 Acidity Measurement . . . . . . . . . . 8

7.2.2 Conductivity and pH Measurements. . . 8

8. ACKNOWLEDGEMENTS. . . . . . . . . . . . . 8 

Simulated Precipitation Reference Materials, III

E. R. Deardorff, T. C. Rains, and W. F. Koch

ABSTRACT

This report describes the preparation of a third series of reference materials for the chemical analysis of natural precipitation samples. These materials were prepared by the National Bureau of Standards (NBS), under the joint sponsorship of the Environmental Protection Agency (EPA), and the U. S. Geological Survey (USGS), and will be used as a means of intercalibrating atmospheric monitoring stations. These materials consist of high and low concentrates which upon dilution simulate the range of anion and cation concentrations typically found in natural rainwater. Two separate reference samples which are to be used undiluted are provided for evaluation of acidity measurements. The analytical methods used to establish the composition of the samples are also described.

\section{INTRODUCTION}

The analysis of the composition of rainfall and other forms of precipitation is an excellent means to monitor global atmospheric pollution. Such measurements must necessarily be made at widely spaced geographical locations, over extended periods of time, and by many independent investigators. It is imperative that the measuring stations be intercalibrated if the data obtained are to be correlated and combined for environmental interpretation. The measurement of a series of substantially identical samples by stations in a measurement system is an accepted method of evaluating laboratory performance for intercalibration purposes.

This report describes work done at the National Bureau of Standards under the sponsorship of EPA to prepare and establish the composition of a series of reference materials intended to be used for the intercalibration of precipitation measurement stations ${ }^{1}$. The materials consist of

${ }^{1}$ This work was performed at the National Bureau of Standards for the Environmental Protection Agency and the U. S. Geological Survey under Interagency Agreement EPA-79-D-F0666 and Purchase Order 84312 , respectively.

CONTRIBUTION OF THE NATIONAL BUREAU OF STANDARDS. NOT SUBJECT TO COPYRIGHT. 
ampoules containing aqueous concentrates that simulate natural precipitation when accurately diluted. Two multicomponent solutions and two solutions specifically designated for acidity measurement were prepared.

This is the third series of solutions prepared for EPA to be used by the World Meteorological Organization (WMO) stations. The details of the first and second series are contained in NBSIR 75-958, "Simulated Precipitation Reference Materials", October 1975, and NBSIR 77-1315 "Simulated Precipitation Reference Materials II", September 1977.

\section{EXPERIMENTAL DETAILS}

\subsection{Genera1 Considerations}

These reference materials are similar in concept to those prepared previously. Two reference solutions, low concentrations (Series 910000), and the other high concentrations (Series 920000) were prepared of specified components at levels similar to those expected in natural samples (Table 1). In addition, two reference materials (Series 930000, and Series 940000) containing 3 microequivalents ( $\mu \mathrm{eq}$ ) and $5 \mu \mathrm{eq}$ of sulfuric acid, respectively, per ampoule are included specifically for the measurement of acidity.

\subsection{Preparation of Reference Materials}

The reference materials were prepared using distilled water whose specific conductance does not exceed 1 micro siemens per centimeter $(1 \mu \mathrm{S} / \mathrm{cm})$ at $25^{\circ} \mathrm{C}$ and reagent grade chemicals. Distilled water in this report refers to this quality of water. The chemicals used and their sources are listed in Table 2. The quantities of chemicals are listed in Table 3 .

The instructions for the preparation of Series 910000 and Series 920000 are as follows:

Ten liters of the required solutions can be prepared using the quantities of reagents set forth in the instructions supplied by EPA (Table 3). The procedure is as follows: Transfer the reagents with the exception of sodium fluoride and lead acetate using distilled water to a one liter volumetric flask and make up nearly to volume with distilled water. Because of its low solubility, add the sodium fluoride at this point and dilute to calibrated volume, Solution A. Transfer the lead acetate to another one liter volumetric flask and dilute to $800 \mathrm{~mL}$. Add 100 $\mathrm{mL}$ of Solution $\mathrm{A}$ by pipet to the lead acetate solution and dilute to calibrated volume, Solution B. 
Transfer by pipet $400 \mathrm{~mL}$ of Solution A to each of two volumetric flasks, four liter capacity, and make up to volume. Filter both four liter solutions and the one liter containing the lead acetate, Solution B, through a Whatman 40 filter paper into a ten liter ground glass stoppered bottle.

Series 930000 and Series 940000 were prepared by the dilution of an appropriate volume of $0.06 \mathrm{~N}$ sulfuric acid to a final volume of 30 liters. The sulfuric acid solution was standardized using two different procedures. In the first, the acid was titrated against THAM (Tris(hydroxymethyl) aminomethane) SRM 723. In addition, the acid was also titrated against a $0.05 \mathrm{~N}$ sodium hydroxide solution that had been previously standardized with potassium acid phthalate, SRM $84 h$.

\subsection{Ampouling}

The bulk solutions were transferred to ampoules using an automatic dispensing and sealing machine belonging to the Office of Standard Reference Materia1s. The ampoules used (Wheaton Cat. No. 176780) were made from borosilicate glass formulated to prevent a change of $\mathrm{pH}$ and to maintain the purity of the contents. They were prescored to eliminate the need for filing.

The dispensing equipment pumps the solution from the storage vessel and reproducibly injects a pre-set volume into the ampoules, and automatically flame seals the ampoules. Ampoules randomly selected for analysis were also weighed to verify the reproducibility of the filling operation. No significant changes in weight were detected in the four solutions during the filling operation.

The ampoules used for Series 910000 and 920000 were of $10 \mathrm{~mL}$ capacity while $20 \mathrm{~mL}$ ampoules were used for the Series 930000 and Series 940000 samples. The dispensing equipment was adjusted to deliver $10 \mathrm{~mL}$ in the first group. But only about $18.4 \mathrm{~mL}$ could be dispensed into the $20 \mathrm{~mL}$ ampoules because delivery of a greater volume resulted in the liquid splashing up onto the neck of the ampoule.

The precision of the ampouling operation is shown by the data in Table 4 .

\subsection{Numbering Sequence}

The ampoules are labeled and numbered in the following sequonces: 
Series 910000 ...... 910001 to 910600

Series 920000 ...... 920001 to 920600

Series 930000 . . . . . 930001 to 931200

Series 940000 ......9940001 to 941200 as follows:

The rationale of the following sequence is illustrated 910001

First digit: Fiscal Year 1979

Second digit: Sample type 1, 2, 3, or 4

Remaining digits: Sample serial number, e.g., 0001

The samples were replaced in the individually compartmented boxes in which the ampoules were received from the manufacturer. Care was exercised to replace them in the boxes in the order in which they were filled. Samples for measurement were selected from these by a random number process. Altogether, 76 ampoules were selected from each of Series 910000, and Series 920000 for this purpose, while 30 were selected from the Series 930000 , and Series 940000 . No differences were found in either mass content or composition that could be attributed to sequence of preparation. Accordingly, it is believed that the samples in each series are substantially uniform with respect to composition and total content. See Table 4.

The samples delivered to EPA and USGS were numbered sequentially, ignoring the gaps resulting from removal of the test samples. However, the actual production sequence could be ascertained should the need arise.

\subsection{Analysis of Ampoules}

Essentially seven ampoules were analyzed for each specific determination. However, for purposes of convenience, all measurements were not made on the same ampoule. The measurement data are summarized in Tables $5,6,7$ and 8 . The methods used for measurement are summarized in the following subsections.

\subsection{1. $\mathrm{pH}$ Measurements}

The $\mathrm{pH}$ measurements were made on diluted samples of the concentrate. The combination $\mathrm{pH}$ electrode was calibrated with $\mathrm{pH} 4.01$ and 7.00 buffers and the sample readings were taken directly from the digital pH meter display. 


\subsubsection{Conductivity Measurements}

The conductivity measurements were made with a dip type conductivity ce11 in the A.C. mode at a frequency of $1 \mathrm{kHz}$. The cel1 constant was determined using a 0.01 demal solution [Jones and Bradshaw, J. Am. Chem. Soc. 55, 1780 (1933)]. Appropriate temperature corrections were made. The values reported were made at $23^{\circ} \mathrm{C}$.

\subsubsection{Acidity Measurements}

The acidity content of each ampoule was determined by coulometric titration of hydrogen ion to the designated $\mathrm{pH}=8.3$.

\subsubsection{Determination of Anions}

The anions fluoride, chloride, nitrate, and sulfate were determined by ion-chromatography. A11 four anions were done sequentially with a single injection. Chromatographic conditions were as follows: eluent $0.003 \mathrm{~mol} / \mathrm{L} \mathrm{NaHCO}_{3}$ and $0.0018 \mathrm{mo} 1 / \mathrm{L} \mathrm{Na}_{2} \mathrm{CO}_{3}$; flow-rate $2 \mathrm{~mL} / \mathrm{minute} ;$ sample 1 oop 100 $\mu \mathrm{L}$; anion columns $3 \times 500 \mathrm{~mm}$ plus $3 \times 150 \mathrm{~mm}$ pre-column; suppressor column $6 \times 250 \mathrm{~mm}$. Baseline resolution was obtained for all four anions with a total elution time of 32 minutes. Three calibration standards containing the four anions were prepared encompassing the range of the samples. Quantitation was performed by interpolation of the first order least squares fit of the calibration standards' peakheight response versus concentration. Each ampoule of series 910000 was diluted to $50 \mathrm{~mL}$, and each ampoule of series 920000 to $140 \mathrm{~mL}$. Results have been normalized to a dilution of $500 \mathrm{~mL}$ per ampoule.

\subsubsection{Analysis for Cations}

\subsubsection{Measurement of Ammonium Ions}

The chosen technique consisted of chemical measurement according to the procedure given in the following reference: C. O. Willits, and C. L. Ogg, "1949 Report of Standardization of Microchemical Methods, Micro Kjeldah1 Nitrogen Determinations", USDA Eastern Regional Research Laboratory, Philadelphia, PA. A micro-Kjeldahl steam distillation apparatus was used to separate the ammonia, released by sodium hydroxide, which was trapped in boric acid. The ammonia was titrated with standardized $0.01 \mathrm{~N}$ hydrochloric acid using methyl purple indicator. 
2.5.5.2. Metals by Atomic Absorption and Flame Emission Spectrometry

A11 of the metallic cations were measured by atomic absorption or flame emission spectrometry. Measurements were made both on the bulk solution and on the ampoules. The contents of an ampoule were quantitatively transferred to a $100 \mathrm{~mL}$ volumetric flask. After addition of $1 \mathrm{~mL}$ of NBS purified hydrochloric acid, the solution was diluted to the calibrated volume. Emission or absorption measurements were made in duplicate. Calibration standards were made by dissolution of pure salts or pure metals.

\section{ANALYTICAL RESULTS}

The analytical results for Series 910000 and Series 920000 are summarized in Tables 5 , and 6 . The symbols used are as follows:

$$
\begin{aligned}
& n=\text { number of samples analyzed } \\
& \bar{x}=\frac{x_{1}+x_{2}+\ldots+x_{n}}{n} \\
& s=\left(\frac{n \sum x^{2}-\left(\sum x\right)^{2}}{n(n-1)}\right)^{1 / 2}
\end{aligned}
$$

The values listed under $\bar{x}$ are the best estimates of various compositional parameters of the solution measured after the contents of each ampoule has been diluted to $500 \mathrm{~mL}$.

The compositional data for Series 930000 and Series 940000 are given in Tables 7 , and 8 . The values reported here have been determined directly on the samples contained in the $20 \mathrm{~mL}$ ampoules without further dilution. The acidity values are based upon combining the contents of two ampoules. The $\mathrm{pH}$ and conductivity values are for undiluted samples but of course are independent of the volume of sample measured.

\section{DISCUSSION}

The samples in each series are believed to be uniform in composition. Every ampoule in each series contains the same amount of liquid within narrow limits. The dilution of the contents should not introduce any errors, provided distilled water is used. The samples can be used to determine the between-laboratories variability within the requirements for precipitation analysis. 


\section{RE-EXAMINATION OF 1975 SAMPLES}

Table 9 shows that there have been no significant changes in the concentrations of the anions.

Most of the cations have remained relatively stable. Copper and lead have decreased significantly, however, as a result of interaction with the walls of the ampoules. Although iron was proposed for the 1975 samples, it was found that it could not be retained at $\mathrm{pH} 6$; it therefore was omitted from this preparation.

In Table 9 under Sample B it is seen that no values for $\mathrm{pH}$ and ammonium ion are reported under the 1979 column. In addition, the acidity measurements are missing for this same year. Unfortunately the supply of ampoules retained from 1975 had been exhausted before these measurements could be obtained.

In the re-examination of 1975 samples, the data reported in Table 9 for 1979 were derived from the analysis of at least two ampoules.

\section{RE-EXAMINATION OF 1977 SAMPLES}

Table 10 shows very few changes in the constituents of the 1977 samples. $\mathrm{SO}_{4}$ and $\mathrm{Ca}$ have increased. Sample 730000 ampoule was rinsed with hydrochloric acid to dissolve the precipitate before analysis of the cations. This resulted in the recovery of the iron that was originally added to the solution, $0.18 \mathrm{mg} / \mathrm{L}$.

The acidity standard Series 740000 has decreased in ueq of acid by 15 percent.

A minimum of two ampoules was used for each determination in 1979 for the re-examination of the 1977 samples.

\section{INSTRUCTIONS FOR USE}

\subsection{Series 910000 and Series 920000}

The samples consist of ampoules of concentrations which simulate rainwater, when diluted to $500 \mathrm{~mL}$. The ampoules are pre-scored to facilitate breaking off the top. Glassware should be thoroughly cleaned and rinsed with distilled water before use. The recommended procedure for preparation of the test sample is as follows:

1. Rinse the outside of the ampoule to remove dust and allow to air dry. 
2. Hold ampoule in a vertical position, tip over and back, and gently tap to transfer any liquid from the top to the body of the ampoule.

3. Hold ampoule with a paper towel (a precaution to prevent injury to hand) and snap off the top at the scored constriction.

4. Place a clean funnel in the neck of a clean $500 \mathrm{~mL}$ volumetric flask and transfer the contents of the ampoule, with gentle shaking as required to facilitate removal of liquid.

5. Rinse the ampoule two times with distilled water and transfer the rinsings to the flask.

6. Add distilled water to the flask to dilute to the calibrated volume and mix contents thoroughly.

7. Treat the resulting solution with the same care and in the same manner as a sample of natural rainwater.

7.2. Series 930000 and Series 940000

The solutions are intended for use without additional dilution.

\subsubsection{Acidity Measurement}

Empty the contents of two ampoules into a clean $100 \mathrm{~mL}$ beaker, according to instructions 1,2 , and 3 in Section 6.1. Hold the inverted ampoule over the beaker until contents have drained as much as possible. Check for visible inclusions of solution in the ampoule and shake again, if required. Any film of solution remaining in the ampoule will not cause significant error.

\subsubsection{Conductivity and $\mathrm{pH}$ Measurements}

Empty the contents of one ampoule into a clean $30 \mathrm{~mL}$ beaker. Remove substantially all the contents by shaking. However, the measurements are not influenced by the quantity of sample used, hence quantitative delivery is not required. It is convenient to measure sample conductivity, followed by measurement of $\mathrm{pH}$ on the same sample.

\section{ACKNOWLEDGEMENTS}

The participation of the following members of the Staff of the Inorganic Analytical Research Division in the analysis 
of these reference materials is gratefully acknowledged:

T. A. Rush, and G. Marinenko. Mr. R. K. Kirby of the NBS Office of Standard Reference Materials was responsible for overseeing the ampouling and labeling of the samples.

The work was performed for the Environmental Protection Agency under Interagency Agreement EPA-IAG-79-DF0666.

Informative discussions with $\mathrm{Mr}$. Vance $\mathrm{R}$. Highsmith, EPA, Project Officer, and Dr. Richard J. Thompson, EMD/EMSL/EPA are gratefully acknowledged. 
Table 1. Target Compositions.

Unit of Concentration $\mathrm{mg} / \mathrm{L}$

\begin{tabular}{|c|c|c|}
\hline Constituent & Series 910000 & Series 920000 \\
\hline $\mathrm{pH}$ & -- & -- \\
\hline Conductivity & -- & -- \\
\hline Acidity & -- & - \\
\hline $\mathrm{SO}_{4}$ & $.73 *$ & $2.23 *$ \\
\hline $\mathrm{SO}_{4}(\mathrm{~S})$ & .24 & .74 \\
\hline $\mathrm{NO}_{3}$ & .816 & 2.138 \\
\hline $\mathrm{NO}_{3}(\mathrm{~N})$ & .182 & .483 \\
\hline $\mathrm{NH}_{4}$ & .208 & .651 \\
\hline $\mathrm{NH}_{4}(\mathrm{~N})$ & .161 & .506 \\
\hline $\mathrm{C} 1$ & .810 & 3.020 \\
\hline$F$ & .143 & .238 \\
\hline $\mathrm{Ca}$ & .200 & .545 \\
\hline $\mathrm{Cd}$ & .049 & .225 \\
\hline $\mathrm{Cu}$ & .070 & .287 \\
\hline K & .146 & .488 \\
\hline $\mathrm{Mg}$ & .050 & .200 \\
\hline Mn & .037 & .151 \\
\hline $\mathrm{Na}$ & .226 & .455 \\
\hline $\mathrm{Ni}$ & .059 & .176 \\
\hline $\mathrm{Pb}$ & .062 & .207 \\
\hline $2 n$ & .065 & .392 \\
\hline $\mathrm{Fe}$ & .032 & .072 \\
\hline
\end{tabular}



Table 2. Chemicals Used for Preparation of Reference
Materials.

\begin{tabular}{|c|c|c|}
\hline Chemical & Formula & Source \\
\hline Calcium Chloride & $\mathrm{CaCl}_{2} \cdot 2 \mathrm{H}_{2} \mathrm{O}$ & $\begin{array}{l}\text { Ma1linckrodt Analytical } \\
\text { Reagent }\end{array}$ \\
\hline Magnesium Sulfate & $\mathrm{MgSO}_{4} \cdot 7 \mathrm{H}_{2} \mathrm{O}$ & E \& A Tested Purity \\
\hline Zinc Nitrate & $\mathrm{Zn}\left(\mathrm{NO}_{3}\right)_{2} \cdot 6 \mathrm{H}_{2} \mathrm{O}$ & Baker Analyzed \\
\hline Cadmium Nitrate & $\mathrm{Cd}\left(\mathrm{NO}_{3}\right)_{2} \cdot 4 \mathrm{H}_{2} \mathrm{O}$ & Fisher Analyzed \\
\hline Cupric Chloride & $\mathrm{CuCl}_{2} \cdot 2 \mathrm{H}_{2} \mathrm{O}$ & B \& A Reagent \\
\hline Cupric Nitrate & $\mathrm{Cu}\left(\mathrm{NO}_{3}\right)_{2} \cdot 3 \mathrm{H}_{2} \mathrm{O}$ & Baker Analyzed \\
\hline Nicke1 Nitrate & $\mathrm{Ni}\left(\mathrm{NO}_{3}\right)_{2} \cdot 6 \mathrm{H}_{2} \mathrm{O}$ & $\begin{array}{l}\text { Mallinckrodt Analytical } \\
\text { Reagent }\end{array}$ \\
\hline Lead Acetate & $\mathrm{Pb}(\mathrm{Ac})_{2} \cdot 3 \mathrm{H}_{2} \mathrm{O}$ & Baker Analyzed \\
\hline Manganese Chloride & $\mathrm{MnCl}_{2} \cdot 4 \mathrm{H}_{2} \mathrm{O}$ & $B$ \& A Reagent \\
\hline Ammonium Chloride & $\mathrm{NH}_{4} \mathrm{Cl}$ & Baker Analyzed \\
\hline Sodium Chloride & $\mathrm{NaCl}$ & $\begin{array}{l}\text { Mallinckrodt Analytical } \\
\text { Reagent }\end{array}$ \\
\hline Sodium Fluoride & $\mathrm{NaF}$ & Fisher Certified \\
\hline Sodium Nitrate & $\mathrm{NaNO}_{3}$ & Baker Analyzed \\
\hline Potassium Nitrate & $\mathrm{KNO}_{3}$ & Baker U1trex \\
\hline Ferric Ammonium Citrate & & Fisher Purified \\
\hline Citric Acid Monohydrate & & Baker Analyzed \\
\hline
\end{tabular}


Table 3. Recipe for NBS Precipitation Reference Materials, III.

$$
\text { Preparation of Stock Solutions (10 liters) }
$$

\section{Chemica1}

$\mathrm{H}_{2} \mathrm{SO}_{4}$ ( $\mu$ eq)

$\mathrm{NH}_{4} \mathrm{Cl}(\mathrm{gm})$

$\mathrm{CaCl}_{2} \cdot 2 \mathrm{H}_{2} \mathrm{O}(\mathrm{gm})$

$\mathrm{NaCl}(\mathrm{gm})$

$\mathrm{NaNO}_{3}(\mathrm{gm})$

$\mathrm{NaF}(\mathrm{gm})$

$\mathrm{Cd}\left(\mathrm{NO}_{3}\right)_{2} \cdot 4 \mathrm{H}_{2} \mathrm{O} \quad(\mathrm{gm})$

$\mathrm{Cu}\left(\mathrm{NO}_{3}\right)_{2} \cdot 3 \mathrm{H}_{2} \mathrm{O}(\mathrm{gm})$

$\mathrm{CuCl}_{2} \cdot 2 \mathrm{H}_{2} \mathrm{O} \quad(\mathrm{gm})$

$\mathrm{KNO}_{3}(\mathrm{gm})$

$\mathrm{MgSO}_{4} \cdot 7 \mathrm{H}_{2} \mathrm{O}(\mathrm{gm})$

$\mathrm{MnCl}_{2} \cdot 4 \mathrm{H}_{2} \mathrm{O}(\mathrm{gm})$

$\mathrm{Ni}\left(\mathrm{NO}_{3}\right)_{2} \cdot 6 \mathrm{H}_{2} \mathrm{O} \quad(\mathrm{gm})$

$\mathrm{Pb}(\mathrm{Ac})_{2} \cdot 3 \mathrm{H}_{2} \mathrm{O} \quad(\mathrm{gm})$

$\mathrm{Zn}\left(\mathrm{NO}_{3}\right)_{2} \cdot 6 \mathrm{H}_{2} \mathrm{O}(\mathrm{gm})$

Ferric Ammonium Citrate (gm)

Citric Acid Monohydrate (gm) $\underline{910000} \quad \underline{920000}$

$5,600 \quad 15,000$

$.3080 \quad .9650$

$.3676 \quad 1.0000$

.2150

.1000

$.1575 \quad .2625$

$.0675 \quad .3084$

.1335

.1894

.2520

.0660

.1450

.0570

.1480

.0923

.8406
.3850

.6315

1.0086

.2720

.4366

.1896

.8926

.2076

3.3622 
Table 4. Precision of Ampouling.

$$
\begin{array}{cccc}
\underline{\text { Series }} & \underline{\mathrm{n}} & \underline{\overline{\mathrm{x}}, \mathrm{g}} & \underline{\mathrm{s}} \\
910000 & 12 & 9.962 & 0.018 \\
920000 & 12 & 9.972 & 0.018 \\
930000 & 12 & 18.30 & 0.022 \\
940000 & 10 & 18.39 & 0.016
\end{array}
$$

\begin{tabular}{|c|c|c|}
\hline $\begin{array}{c}\text { Random } \\
\text { Ampoules } \\
\text { Listed } \\
\text { Numerically } \\
\end{array}$ & $\begin{array}{l}\text { Ampoules } \\
\text { in Order } \\
\text { of Weighing }\end{array}$ & $\begin{array}{l}\text { Weight } \\
\text { of } \\
\text { Liquid, } \\
\text { grams } \\
\end{array}$ \\
\hline 1 & 1 & 9.9986 \\
\hline 80 & 11 & 9.9988 \\
\hline 145 & 5 & 9.9612 \\
\hline 240 & 4 & 9.9600 \\
\hline 289 & 9 & 9.9518 \\
\hline 368 & 7 & 9.9578 \\
\hline 433 & 10 & 9.9605 \\
\hline 528 & 3 & 9.9572 \\
\hline 577 & 2 & 9.9537 \\
\hline 672 & 8 & 9.9824 \\
\hline 721 & 6 & 9.9825 \\
\hline 816 & 12 & 9.9948 \\
\hline
\end{tabular}

To demonstrate that there is no systematic trend in the sampling operations, randomly selected ampoules and the weights of liquid obtained for the 920000 Series are given below: 
Table 5. Analytical Data for Series 910000.

\begin{tabular}{|c|c|c|c|c|}
\hline Constituent & Unit & $\underline{\mathrm{n}}$ & $\underline{\bar{x}}$ & $\underline{s}$ \\
\hline $\mathrm{pH}$ & & 7 & 5.03 & 0.24 \\
\hline Conductivity & $\mu \mathrm{S} \cdot \mathrm{cm}^{-1}$ & 7 & 13.20 & .08 \\
\hline Acidity & $\mu \mathrm{eq} / \mathrm{amp}$ & 7 & 17.38 & .45 \\
\hline $\mathrm{SO}_{4}$ & $\mathrm{mg} / \mathrm{L}$ & 7 & .779 & .008 \\
\hline $\mathrm{SO}_{4}(\mathrm{~S})$ & $\mathrm{mg} / \mathrm{L}$ & 7 & .260 & .003 \\
\hline $\mathrm{NO}_{3}$ & $\mathrm{mg} / \mathrm{L}$ & 7 & .826 & .002 \\
\hline $\mathrm{NO}_{3}(\mathrm{~N})$ & $\mathrm{mg} / \mathrm{L}$ & 7 & .186 & .0005 \\
\hline $\mathrm{NH}_{4}$ & $\mathrm{mg} / \mathrm{L}$ & 7 & .214 & .010 \\
\hline $\mathrm{NH}_{4}(\mathrm{~N})$ & $\mathrm{mg} / \mathrm{L}$ & 7 & .166 & .008 \\
\hline $\mathrm{C} 1$ & $\mathrm{mg} / \mathrm{L}$ & 7 & .908 & .008 \\
\hline F & $\mathrm{mg} / \mathrm{L}$ & 7 & .154 & .002 \\
\hline $\mathrm{Ca}$ & $\mathrm{mg} / \mathrm{L}$ & 7 & .248 & .0014 \\
\hline $\mathrm{Cd}$ & $\mathrm{mg} / \mathrm{L}$ & 7 & .051 & .0004 \\
\hline $\mathrm{Cu}$ & $\mathrm{mg} / \mathrm{L}$ & 7 & .073 & .0003 \\
\hline K & $\mathrm{mg} / \mathrm{L}$ & 7 & .156 & .001 \\
\hline $\mathrm{Mg}$ & $\mathrm{mg} / \mathrm{L}$ & 7 & .056 & .0006 \\
\hline $\mathrm{Mn}$ & $\mathrm{mg} / \mathrm{L}$ & 7 & .038 & .0006 \\
\hline $\mathrm{Na}$ & $\mathrm{mg} / \mathrm{L}$ & 7 & .284 & .0050 \\
\hline $\mathrm{Ni}$ & $\mathrm{mg} / \mathrm{L}$ & 7 & .061 & .0003 \\
\hline $\mathrm{Pb}$ & $\mathrm{mg} / \mathrm{L}$ & 7 & .070 & .0006 \\
\hline $\mathrm{Zn}$ & $\mathrm{mg} / \mathrm{L}$ & 7 & .066 & .0006 \\
\hline $\mathrm{Fe}$ & $\mathrm{mg} / \mathrm{L}$ & 7 & .030 & .0006 \\
\hline
\end{tabular}


Table 6. Analytical Data for Series 920000 .

\begin{tabular}{|c|c|c|c|c|}
\hline Constituent & Unit & $\underline{\mathrm{n}}$ & $\underline{\bar{x}}$ & $\underline{s}$ \\
\hline $\mathrm{pH}$ & & 7 & 4.35 & 0.12 \\
\hline Conductivity & $\mu \mathrm{S} \cdot \mathrm{cm}^{-1}$ & 7 & $43.49^{\circ}$ & .08 \\
\hline Acidity & $\mu \mathrm{eq} / \mathrm{amp}$ * & 7 & 66.02 & .75 \\
\hline $\mathrm{SO}_{4}$ & $\mathrm{mg} / \mathrm{L}$ & 7 & 2.349 & .024 \\
\hline $\mathrm{SO}_{4}(\mathrm{~S})$ & $\mathrm{mg} / \mathrm{L}$ & 7 & .776 & .008 \\
\hline $\mathrm{NO}_{3}$ & $\mathrm{mg} / \mathrm{L}$ & 7 & 2.147 & .006 \\
\hline $\mathrm{NO}_{3}(\mathrm{~N})$ & $\mathrm{mg} / \mathrm{L}$ & 7 & .485 & .001 \\
\hline $\mathrm{NH}_{4}$ & $\mathrm{mg} / \mathrm{L}$ & 7 & .660 & .013 \\
\hline $\mathrm{NH}_{4}(\mathrm{~N})$ & $\mathrm{mg} / \mathrm{L}$ & 7 & .514 & .010 \\
\hline $\mathrm{C} 1$ & $\mathrm{mg} / \mathrm{L}$ & 7 & 3.274 & .014 \\
\hline $\mathrm{F}$ & $\mathrm{mg} / \mathrm{L}$ & 7 & .256 & .003 \\
\hline $\mathrm{Ca}$ & $\mathrm{mg} / \mathrm{L}$ & 7 & .654 & .0048 \\
\hline $\mathrm{Cd}$ & $\mathrm{mg} / \mathrm{L}$ & 7 & .224 & .0034 \\
\hline $\mathrm{Cu}$ & $\mathrm{mg} / \mathrm{L}$ & 7 & .294 & .0019 \\
\hline K & $\mathrm{mg} / \mathrm{L}$ & 7 & .506 & .0074 \\
\hline $\mathrm{Mg}$ & $\mathrm{mg} / \mathrm{L}$ & 7 & .226 & .0026 \\
\hline Mn & $\mathrm{mg} / \mathrm{L}$ & 7 & .154 & .0006 \\
\hline $\mathrm{Na}$ & $\mathrm{mg} / \mathrm{L}$ & 7 & .558 & .0078 \\
\hline $\mathrm{Ni}$ & $\mathrm{mg} / \mathrm{L}$ & 7 & .185 & .0010 \\
\hline $\mathrm{Pb}$ & $\mathrm{mg} / \mathrm{L}$ & 7 & .214 & .0070 \\
\hline $\mathrm{Zn}$ & $\mathrm{mg} / \mathrm{L}$ & 7 & .402 & .0042 \\
\hline $\mathrm{Fe}$ & $\mathrm{mg} / \mathrm{L}$ & 7 & .071 & .0019 \\
\hline
\end{tabular}

ampoule 
Table 7. Compositional Data for Series 930000.

\begin{tabular}{|c|c|c|c|}
\hline Constituent & Unit & $\underline{n}$ & $\underline{\bar{x}}$ \\
\hline $\mathrm{pH}$ & & 9 & 3.91 \\
\hline Conductivity & $\mu \mathrm{S} \cdot \mathrm{cm}^{-1}$ & 7 & 69.12 \\
\hline Acidity & $\mu \mathrm{eq} / 2$ amp* & 7 & 5.90 \\
\hline
\end{tabular}

ampoules 
Table 8. Compositional Data for Series 940000

$\begin{array}{llrrr}\text { Constituent } & \underline{\text { Unit }} & \underline{\mathrm{n}} & \underline{\bar{x}} & \underline{\mathrm{s}} \\ \mathrm{pH} & & 10 & 3.62 & 0.015 \\ \text { Conductivity } & \mu \mathrm{S} \cdot \mathrm{cm}^{-1} & 7 & 121.44 & .22 \\ \text { Acidity } & \mu \mathrm{eq} / 2 \mathrm{amp} * & 7 & 9.98 & .40\end{array}$

* ampoules 
Table 9. Re-examination of 1975 Samples.

\begin{tabular}{|c|c|c|c|c|c|c|c|}
\hline Constituent & Unit & 1975 & 1977 & $\underline{1979}$ & 1975 & 1977 & 1979 \\
\hline $\mathrm{pH}$ & & 6.18 & & & 6.15 & & \\
\hline Conductivity & $\mu \mathrm{S} \cdot \mathrm{cm}^{-1}$ & 5.8 & & 5.10 & 18.3 & & 17.15 \\
\hline Acidity & $\mu$ eq / amp* & 4.9 & & & 5.0 & & \\
\hline $\mathrm{SO}_{4}$ & $\mathrm{mg} / \mathrm{L}$ & 1.08 & 1.09 & 1.12 & 3.57 & 3.81 & 3.77 \\
\hline $\mathrm{SO}_{4}(\mathrm{~S})$ & $\mathrm{mg} / \mathrm{L}$ & .361 & .365 & .373 & 1.19 & 1.27 & 1.26 \\
\hline $\mathrm{NO}_{3}$ & $\mathrm{mg} / \mathrm{L}$ & .115 & .146 & .111 & .664 & .700 & .674 \\
\hline $\mathrm{NO}_{3}(\mathrm{~N})$ & $\mathrm{mg} / \mathrm{L}$ & .026 & .033 & .025 & .150 & .158 & .152 \\
\hline $\mathrm{NH}_{4}$ & $\mathrm{mg} / \mathrm{L}$ & .109 & & .08 & .49 & & \\
\hline $\mathrm{NH}_{4}(\mathrm{~N})$ & $\mathrm{mg} / \mathrm{L}$ & .089 & & .06 & .38 & & \\
\hline $\mathrm{C} 1$ & $\mathrm{mg} / \mathrm{L}$ & .106 & & .128 & 1.25 & & 1.08 \\
\hline $\mathrm{F}$ & $\mathrm{mg} / \mathrm{L}$ & .102 & & .108 & .096 & & .097 \\
\hline $\mathrm{Ca}$ & $\mathrm{mg} / \mathrm{L}$ & .099 & .084 & .100 & .442 & .370 & .388 \\
\hline $\mathrm{Cd}$ & $\mathrm{mg} / \mathrm{L}$ & .030 & .030 & .032 & .116 & .115 & .096 \\
\hline $\mathrm{Cu}$ & $\mathrm{mg} / \mathrm{L}$ & .052 & .040 & .033 & .088 & .035 & .020 \\
\hline K & $\mathrm{mg} / \mathrm{L}$ & .063 & .066 & .067 & .102 & .107 & .103 \\
\hline $\mathrm{Mg}$ & $\mathrm{mg} / \mathrm{L}$ & .086 & .086 & .087 & .456 & .454 & .396 \\
\hline Mn & $\mathrm{mg} / \mathrm{L}$ & .052 & .054 & .052 & .081 & .085 & .070 \\
\hline $\mathrm{Na}$ & $\mathrm{mg} / \mathrm{L}$ & .153 & .166 & .166 & .516 & .546 & .488 \\
\hline $\mathrm{Ni}$ & $\mathrm{mg} / \mathrm{L}$ & .021 & .022 & .021 & .104 & .113 & .087 \\
\hline $\mathrm{Pb}$ & $\mathrm{mg} / \mathrm{L}$ & .018 & .009 & .010 & .088 & .058 & .070 \\
\hline $\mathrm{Zn}$ & $\mathrm{mg} / \mathrm{L}$ & .021 & .020 & .020 & .095 & .089 & .064 \\
\hline $\mathrm{Fe}$ & $\mathrm{mg} / \mathrm{L}$ & - - - & $\ldots$ & $-\ldots$ & - - - & - . - & - - - \\
\hline
\end{tabular}

ampoule 
Table 9. Re-examination of 1975 Samples.

(continued)

\begin{tabular}{|c|c|c|c|c|c|c|c|}
\hline Constituent & Unit & $\underline{1975}$ & 1977 & $\underline{1979}$ & $\underline{1975}$ & 1977 & 1979 \\
\hline $\mathrm{pH}$ & & 6.20 & & 5.75 & 6.07 & & 5.78 \\
\hline Conductivity & $\mu \mathrm{S} \cdot \mathrm{cm}^{-1}$ & 59.8 & & 57.02 & 117 & & 112 \\
\hline Acidity & $\mu \mathrm{eq} / \mathrm{amp} *$ & 25 & & & 47 & & \\
\hline $\mathrm{SO}_{4}$ & $\mathrm{mg} / \mathrm{L}$ & 5.01 & 5.01 & 4.79 & 10.0 & 9.90 & 9.80 \\
\hline $\mathrm{SO}_{4}(\mathrm{~S})$ & $\mathrm{mg} / \mathrm{L}$ & 1.67 & 1.67 & 1.60 & 3.33 & 3.30 & 3.27 \\
\hline $\mathrm{NO}_{3}$ & $\mathrm{mg} / \mathrm{L}$ & 6.64 & 6.64 & 6.64 & 10.89 & 10.89 & 10.95 \\
\hline $\mathrm{NO}_{3}(\mathrm{~N})$ & $\mathrm{mg} / \mathrm{L}$ & 1.50 & 1.50 & 1.50 & 2.46 & 2.46 & 2.47 \\
\hline $\mathrm{NH}_{4}$ & $\mathrm{mg} / \mathrm{L}$ & 2.46 & & 2.48 & 4.63 & 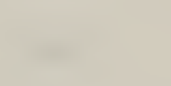 & 4.61 \\
\hline $\mathrm{NH}_{4}(\mathrm{~N})$ & $\mathrm{mg} / \mathrm{L}$ & 1.91 & & 1.93 & 3.60 & & 3.59 \\
\hline $\mathrm{C} 1$ & $\mathrm{mg} / \mathrm{L}$ & 7.63 & & 7.69 & 17.79 & & 18.96 \\
\hline F & $\mathrm{mg} / \mathrm{L}$ & .195 & & .184 & .296 & & .289 \\
\hline $\mathrm{Ca}$ & $\mathrm{mg} / \mathrm{L}$ & 1.23 & 1.04 & 1.21 & 2.84 & 2.42 & 2.80 \\
\hline $\mathrm{Cd}$ & $\mathrm{mg} / \mathrm{L}$ & .578 & .576 & .564 & 1.01 & 0.99 & .99 \\
\hline $\mathrm{Cu}$ & $\mathrm{mg} / \mathrm{L}$ & .200 & .104 & .088 & .393 & .174 & .157 \\
\hline K & $\mathrm{mg} / \mathrm{L}$ & 1.01 & 1.01 & 1.04 & 3.06 & 2.92 & 3.24 \\
\hline $\mathrm{Mg}$ & $\mathrm{mg} / \mathrm{L}$ & .729 & .712 & .720 & .922 & .936 & .906 \\
\hline Mn & $\mathrm{mg} / \mathrm{L}$ & .100 & .103 & .098 & .200 & .204 & .202 \\
\hline $\mathrm{Na}$ & $\mathrm{mg} / \mathrm{L}$ & 2.46 & 2.54 & 2.58 & 5.44 & 5.46 & 5.72 \\
\hline $\mathrm{Ni}$ & $\mathrm{mg} / \mathrm{L}$ & .506 & .560 & .522 & 1.01 & 1.03 & 1.05 \\
\hline $\mathrm{Pb}$ & $\mathrm{mg} / \mathrm{L}$ & .152 & .105 & .124 & .110 & .062 & .074 \\
\hline $\mathrm{Zn}$ & $\mathrm{mg} / \mathrm{L}$ & .307 & .284 & .304 & .610 & .626 & .612 \\
\hline $\mathrm{Fe}$ & $\mathrm{mg} / \mathrm{L}$ & -- & $\cdots$ & $\cdots$ & - - & $\cdots$ & -- \\
\hline
\end{tabular}

ampoule 
Table 10. Re-examination of 1977 Samples.

710000

720000

730000

\begin{tabular}{|c|c|c|c|c|c|c|c|}
\hline $\begin{array}{l}\text { Constit- } \\
\text { uent }\end{array}$ & Unit & 1977 & 1979 & $\begin{array}{r}1977 \\
\end{array}$ & 1979 & 1977 & 1979 \\
\hline $\mathrm{pH}$ & & 4.48 & 4.25 & 4.08 & 4.07 & 5.98 & 5.86 \\
\hline $\begin{array}{l}\text { Conduc- } \\
\text { tivity }\end{array}$ & $\mu \mathrm{S} \cdot \mathrm{cm}^{-1}$ & 28.84 & 30.89 & 77.9 & 84.4 & 190.5 & 205.2 \\
\hline Acidity & $\mu e q / a m p *$ & 37.57 & 30.06 & 59.94 & 53.69 & 52.5 & 39.80 \\
\hline $\mathrm{SO}_{4}$ & $\mathrm{mg} / \mathrm{L}$ & 2.66 & 3.25 & 7.90 & 9.96 & 9.94 & 10.0 \\
\hline $\mathrm{SO}_{4}(\mathrm{~S})$ & $\mathrm{mg} / \mathrm{L}$ & .89 & 1.08 & 2.64 & 3.32 & 3.32 & 3.33 \\
\hline $\mathrm{NO}_{3}$ & $\mathrm{mg} / \mathrm{L}$ & .503 & .53 & 3.02 & 3.18 & 14.50 & 15.3 \\
\hline $\mathrm{NO}_{3}(\mathrm{~N})$ & $\mathrm{mg} / \mathrm{L}$ & .114 & .120 & .68 & .72 & 3.27 & 3.45 \\
\hline $\mathrm{NH}_{4}$ & $\mathrm{mg} / \mathrm{L}$ & .107 & .115 & 1.07 & 1.08 & 10.18 & 10.14 \\
\hline $\mathrm{NH}_{4}(\mathrm{~N})$ & $\mathrm{mg} / \mathrm{L}$ & .084 & .089 & .82 & .82 & 7.93 & 7.89 \\
\hline $\mathrm{Cl}$ & $\mathrm{mg} / \mathrm{L}$ & 1.35 & .961 & 7.22 & 7.75 & 42.4 & 48.72 \\
\hline $\mathrm{F}$ & $\mathrm{mg} / \mathrm{L}$ & .046 & .039 & .0997 & .087 & .103 & .093 \\
\hline $\mathrm{Ca}$ & $\mathrm{mg} / \mathrm{L}$ & .0766 & .089 & .766 & .844 & 5.98 & 7.14 \\
\hline $\mathrm{Cd}$ & $\mathrm{mg} / \mathrm{L}$ & .0230 & .022 & .0572 & .056 & .114 & .113 \\
\hline $\mathrm{Cu}$ & $\mathrm{mg} / \mathrm{L}$ & .0360 & .034 & .192 & .204 & 1.012 & 1.02 \\
\hline K & $\mathrm{mg} / \mathrm{L}$ & .199 & .206 & .994 & 1.016 & 4.94 & 5.18 \\
\hline $\mathrm{Mg}$ & $\mathrm{mg} / \mathrm{L}$ & .110 & .111 & 1.12 & 1.14 & - & - \\
\hline Mn & $\mathrm{mg} / \mathrm{L}$ & .0296 & .029 & .0586 & .058 & .0846 & .083 \\
\hline $\mathrm{Na}$ & $\mathrm{mg} / \mathrm{L}$ & .151 & .169 & 2.86 & 2.82 & 9.66 & 10.1 \\
\hline $\mathrm{Ni}$ & $\mathrm{mg} / \mathrm{L}$ & .0338 & .031 & .0948 & .091 & .518 & .518 \\
\hline $\mathrm{Pb}$ & $\mathrm{mg} / \mathrm{L}$ & .0232 & .023 & .0988 & .101 & 1.04 & 1.14 \\
\hline $\mathrm{Zn}$ & $\mathrm{mg} / \mathrm{L}$ & .0344 & .034 & .198 & .202 & 1.05 & 1.04 \\
\hline $\mathrm{Fe}$ & $\mathrm{mg} / \mathrm{L}$ & .0214 & .022 & .0612 & .068 & .076 & .163 \\
\hline
\end{tabular}

ampoule 
Table 10. Re-examination of 1977 Samples.

(continued)

\section{0}

\begin{tabular}{|c|c|c|}
\hline $\begin{array}{l}\text { Constit- } \\
\text { uent }\end{array}$ & Unit & 1977 \\
\hline $\mathrm{pH}$ & & 3.81 \\
\hline $\begin{array}{l}\text { Conduc- } \\
\text { tivity }\end{array}$ & $\mu \mathrm{S} \cdot \mathrm{cm}^{-1}$ & 80.0 \\
\hline Acidity & $\mu$ eq/amp* & 9.32 \\
\hline
\end{tabular}





\begin{tabular}{|c|c|c|}
\hline $\begin{array}{l}\text { U.S. DEPT. OF COMM. } \\
\text { BIBLIOGRAPHIC DATA } \\
\text { SHEET }\end{array}$ & $\begin{array}{l}\text { 1. PUBLICATION OR REPORT NO. } \\
\text { NBSIR 79-1953 }\end{array}$ & W \\
\hline 4. TITLE AND SUBTITLE & $\therefore$ - • & $\begin{array}{l}\text { 5. Publication Date } \\
\text { October } 1980\end{array}$ \\
\hline \multicolumn{2}{|c|}{ Simulated Precipitation Reference Materials, III } & 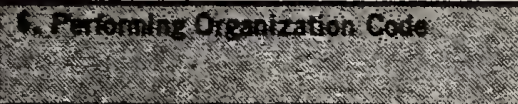 \\
\hline \multicolumn{2}{|c|}{$\begin{array}{l}\text { 7. AUTHOR(S) } \\
\text { E. R. Deardorff, T. C. Rains, and W. F. Koch }\end{array}$} & 8. Performing Organ. Report No. \\
\hline \multirow{2}{*}{\multicolumn{2}{|c|}{ 9. PERFORMING ORGANIZATION NAME AND ADDRESS }} & 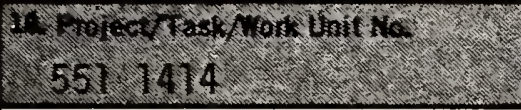 \\
\hline & & 11. Contract/Grant No. \\
\hline \multicolumn{2}{|c|}{$\begin{array}{l}\text { 12. SPONSORING ORGANIZATION NAME AND COMPLETE ADDRESS (Stroot, City, Stato, ZIP) } \\
\text { U.S. Environmental Protection Agency } \\
\text { Environmental Research Center } \\
\text { Research Triangle Park, NC } 27717 \\
\text { and }\end{array}$} & 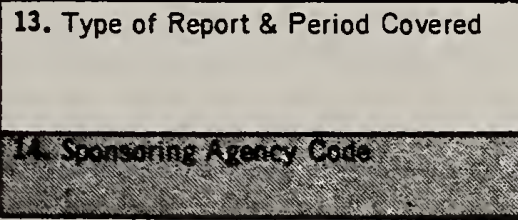 \\
\hline \multicolumn{3}{|c|}{$\begin{array}{ll}\text { 15. SUPPLEMENTARY NOTES } & \text { U.S. Department of the Interior } \\
& \text { Geological Survey, Box 25046, MS 204C, Denver, CO } 80226\end{array}$} \\
\hline
\end{tabular}

16. ABSTRACT (A 200-word or less factual summary of most sigrificant information. If document includes a significant bibliography or literature survoy, mention it hero.)

This report describes the preparation of a third series of reference materials for the chemical analysis of natural precipitation samples. These materials were prepared by the National Bureau of Standards (NBS), under the joint sponsorship of the Environmental Protection Agency (EPA), and the U. S. Geological Survey (USGS), and will be used as a means of intercalibrating atmospheric monitoring stations. These materials consist of high and low concentrates which upon dilution simulate the range of anion and cation concentrations typically found in natural rainwater. Two separate reference samples which are to be used undiluted are provided for evaluation of acidity measurements. The analytical methods used to establish the composition of the samples are also described.

17. KEY WORDS (six to twelve entries; alphebetical order; capitaize only the first letter of the first key word unless a proper name; soperated by semicolons)

Chemical analysis; rainwater analysis; reference materials

\begin{tabular}{|l|c|}
\hline $\begin{array}{l}\text { 19. SECURITY CLASS } \\
\text { (THIS REPORT) } \\
\text { UNCLASSIFIED }\end{array}$ & $\begin{array}{l}\text { 21. NO. OF } \\
\text { PRINTED PAGES }\end{array}$ \\
\hline $\begin{array}{l}\text { 20. SECURITY CLASS } \\
\text { (THIS PAGE) }\end{array}$ & 24 \\
UNCLASSIFIED & $\$ 5.00$ \\
\hline
\end{tabular}

Order From Sup. of Doc., U.S. Government Printing Office, Washington, DC 20402, SD Stock No. SNO03-003-

X] Order From National Technical Information Service (NTIS), Springfield, VA. 22161 


